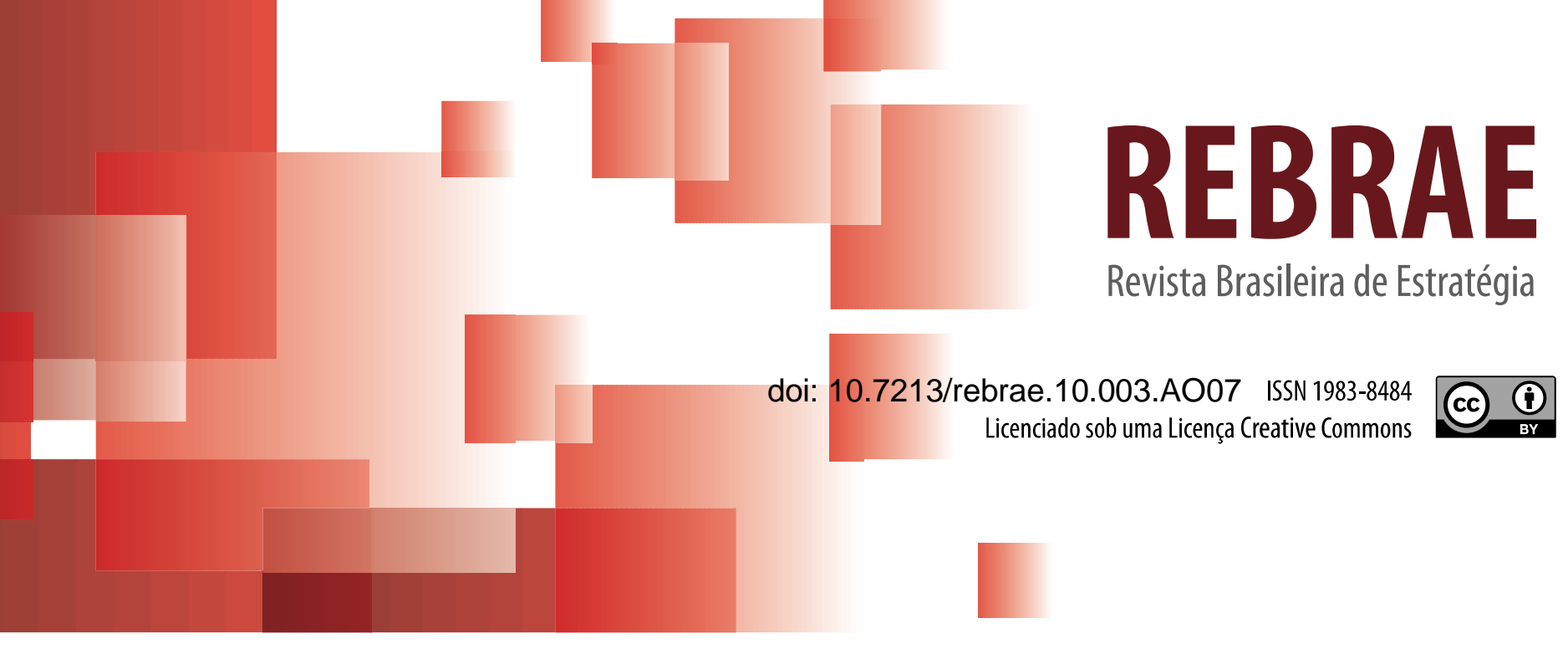

\title{
Analysis of the internationalization strategies of Colombian banking services companies be- tween 2000 and 2015
}

Andrés Mauricio Chavarro Jiménez[a], Georgina Fernández Álvarez ${ }^{[b]}$, José G. VargasHernández ${ }^{[c]}$

[a] Maestría en Negocios y Estudios Económicos. Centro Universitario de Ciencias Económico Administrativas. Universidad de Guadalajara, Zapopan, Jalisco, México. andres.chavarrojimenez@gmail.com

[b] Universitario de Ciencias Económico Administrativas. Universidad de Guadalajara, Zapopan, Jalisco, México.georgina_fdez@outlook.es

[c] Centro Universitario de Ciencias económico administrativas, Universidad de Guadalajara Zapopan, Jalisco, 45100, México jvargas2006@gmail.com

\begin{abstract}
This article analyzes the internationalization strategies of Colombian banking services companies between 2000 and 2015 and analyzes their internationalization process in light of the theory of eclectic theory of Dunning (1988). For this, a review of the internationalization literature is made, emphasizing the OLI model. Next, the internationalization strategies of Colombian banking services companies are presented during the period in question. Finally, it is analyzed the internationalization of Colombian banking to Central America through the Eclectic theory.
\end{abstract}

Keywords: Internationalization strategy, banking services, Colombia.

\section{Introduction}

Foreign direct investment (FDI), which for the most part flows between developed countries has increased considerably towards emerging countries. As a result of this, Latin America and the Caribbean have seen the flow of Foreign Direct Invest- 
ment (FDI) to a large extent. FDI inflows averaged \$ 47 million for the region between 1993 and 1998, \$ 67.5 million in 2004 and \$ 182 million in 2013 (UNCTAD, $2010,2014)$. This in spite of the economic crisis of 2008, which had a significant impact on the FDI that the developing countries received. However, in 2014 there was a slight decline (ECLAC, 2015).

Similarly, outward FDI inflows from emerging countries to developed countries and other emerging countries have grown considerably since the 1990s. In Latin America the largest generators of FDI in its order are Mexico, Chile and Colombia. However, only the third had a growth in FDI between 2012 and 2013 (UNCTAD, 2014).

Given the stability and good performance of the Colombian banks, compared to the banks of the region (ASOBANCARIA, 2015) and short-term as the departure of HSBC from several Latin American countries allowed Colombian banks to start a second stage of internationalization, Mainly to Central America.

A second stage, which comes after the first internationalization efforts in the mid-1970s with the opening of the first subsidiaries in Panama and the United States. Initially, a theoretical framework on internationalization is presented, through different approaches. Then, it is explained the internationalization processes of the main Colombian banks, Bancolombia, Grupo Aval which includes Banco de Bogotá and Banco de Occidente and Banco Davivienda. Based on the above, a discussion is carried out in order to understand the internationalization strategies of Colombian banks and to analyze their internationalization process towards Central America from Dunning's Eclectic theory (1988) of literature, where, in addition to reviewing key concepts to the present article, emphasis is placed on eclectic theory. The objective of the article and its methodology is presented below.

Next, the framework of the investigation is presented, which presents the context of the Colombian banks and the banks under investigation. Finally, the discussion presents the strategies used by Colombian banks and an analysis of the internationalization of Colombian banking to Central America in the light of the eclectic theory of Dunning (1988).

\section{Literature review}

Evered (1983) mentions that it is important, in order to understand the core of a concept's meaning to examine the context in which it was first used, to understand the context and purpose of this essay, it is pertinent to clarify some concepts that are used within the work. Mainly, it is defined strategy by Grant (1991) as "the game that an organization makes between its internal resources and abilities ... and the opportunities and risks created by its external environment", therefore, in clearer terms, it is considered a strategy as those actions that are the result of identifying the resources and capabilities that the company has, which allow it to take advantage of the opportunities located in the environment. One of the strategies followed by different companies are the internationalization strategies.

The definition of internationalization of the company is given by Villareal (2006) which is considered the most complete at present is:

A corporate growth strategy for international geographical diversification, through a long-term evolutionary and dynamic process that gradually 
affects the different activities of the value chain and the organizational structure of the company with a commitment and increasing involvement of its resources and Capabilities (Page 303).

Another definition is given by Korsakiene and Tvaronaviciene (2012) with the globalization of economies and Calof and Beamish (1995, p116) who define internationalization as "the process of adapting business operations (strategy, structure, resources, Etc.) with the international environment ".

\section{Theories of internationalization}

The theory of internationalization has its beginnings in the mid-1970s influenced by the work of Williamson (1975), which is based on the transaction costs of the company, followed by the work shown in table 1 . in which are presented the different theories of internationalization, showing the key element of each of them and the authors. These are divided into two sections, in static environments and dynamic environments, pretending with the dynamic environment to understand how and why companies are internationalized.

Table 1. Theories of internationalization

\begin{tabular}{|c|c|c|c|}
\hline Static & Classic theory & $\begin{array}{l}\text { Comparative advantage } \\
\text { between nations }\end{array}$ & Ohlin (1933) \\
\hline Static & $\begin{array}{l}\text { Theory of monopoly } \\
\text { advantage. }\end{array}$ & $\begin{array}{l}\text { Exclusive competitive ad- } \\
\text { vantage (monopolistic } \\
\text { nature) }\end{array}$ & $\begin{array}{c}\text { Kindleberger } \\
\quad(1968) \\
\text { Hymer (1976 }\end{array}$ \\
\hline Static & $\begin{array}{c}\text { Internationalization } \\
\text { theory }\end{array}$ & Transaction costs & $\begin{array}{c}\text { Bucley and Cason } \\
(1976,1979)\end{array}$ \\
\hline Static & Eclectic theory & $\begin{array}{l}\text { Property, Internationaliza- } \\
\text { tion and location ad- } \\
\text { vantages }\end{array}$ & Dunning (1979) \\
\hline Dynamic & Uppsula model & $\begin{array}{c}\text { Gradual process based on } \\
\text { learning }\end{array}$ & $\begin{array}{l}\text { Johanson and } \\
\text { Vahine (1977) }\end{array}$ \\
\hline Dynamic & Innovation model & $\begin{array}{l}\text { Gradual process based on } \\
\text { firm innovation }\end{array}$ & $\begin{array}{c}\text { Bilkey and Tesar } \\
(1977,1990)\end{array}$ \\
\hline Dynamic & Born-Global & $\begin{array}{l}\text { Accelerated process of } \\
\text { internationalization }\end{array}$ & $\begin{array}{l}\text { Oviatt and MacDou- } \\
\text { gall (1994) }\end{array}$ \\
\hline Dynamic & Network approach & $\begin{array}{l}\text { Management of interna- } \\
\text { tional relations }\end{array}$ & $\begin{array}{l}\text { Johanson and } \\
\text { Mattsson (1988, } \\
\text { 1993) }\end{array}$ \\
\hline Dynamic & $\begin{array}{l}\text { Resource-based } \\
\text { approach }\end{array}$ & $\begin{array}{l}\text { Sustainable and unique } \\
\text { difficult to imitate attrib- } \\
\text { utes }\end{array}$ & $\begin{array}{c}\text { Penrose (1959) } \\
\text { Wemerfelt (1984) } \\
\text { Grant (1996). }\end{array}$ \\
\hline
\end{tabular}

Source: Garcés and Fong (2014).

\section{Eclectic theory}

The eclectic theory has its beginnings with investigations done by Dunning from the year 1979 in which it considers that the reach, the form and the production of international way are given by three advantages, which we can observe in table 2 . 
Table 2. Advantages of eclectic theory.

\begin{tabular}{|cc|}
\hline ADVANTAGE & FOCUS \\
\hline $\begin{array}{c}\text { Specific advantages or } \\
\text { advantages of owner- } \\
\text { ship }\end{array}$ & Possession of specific assets of the other companies. \\
\hline $\begin{array}{c}\text { Advantages of inter- } \\
\text { nalization }\end{array}$ & $\begin{array}{c}\text { Internalize transactions in the company instead of con- } \\
\text { tracting them out. }\end{array}$ \\
\hline Location Advantages. & Take advantage of location-specific advantages \\
\hline
\end{tabular}

Source: Authors based on Dunning (2001)

Internalization is a relevant factor in internationalization. This contribution, based on Coase's proposals (1937), emphasizes that the market failures generated by internalization not only happen in the local market, but also abroad. Market failures, such as transaction costs, lead companies to develop complementary activities on their own instead of taking the costs of hiring in the market. Therefore, it is possible to affirm that the multinational company, in order to take on the imperfections that appear in the foreign markets, internalizes the activities. In addition, when the multinational company organizes an internal market abroad, the specific advantages of the country result in specific advantages of the firm (Williams, 1997).

Advantages related to property mainly refer to intangible assets. Being the possession of these assets allows the multinational company to compete efficiently abroad. Dunning (1988) highlights three factors that determine ownership advantages. 1) Access to markets or resources; 2) Access to the parent company's endowments at a very low marginal cost; and 3) Possibility of ownership of host country factors.

Finally, the advantages related to localization. These advantages are considered to be interrelated with the advantages of ownership and internalization. It is these location advantages that determine the host country of the investment. Factors such as prices of inputs, barriers to trade, tax rates, among others, are part of the relevant aspects for localization. Therefore, Willams (1997) considers that there is a sequence in the process of internationalization. Initially, a property advantage should be available, prior to the intention to internalize a market failure. Finally, after the internalization, are the localization factors together with the factors of internalization, which will determine the how and the where of the investment.

The use of the three types of advantages mentioned above leads companies to internationalize through foreign direct investment (Dunning, 2001). It is important to mention that Foreign Direct Investment is considered those cross-border investment transactions carried out by a foreign investor in a national company, in order to establish a lasting relationship. Through this investment, a total or partial control of the company receiving the investment is achieved. This includes mergers and acquisitions or investments in new companies. The three main items related to FDI movements are new investments, reinvestment of profits and accounts between companies (Secretaría de Economía, s.f.).

From the second half of the 1990s, mergers and acquisitions were by far the largest part of the activity of multinational companies. Understanding by merger as 
the union of two or more people who decide to gather their estates to form a new society, and as acquisition the total purchase of shares of an economic entity, both actions represent a corporate strategy. These mergers and acquisitions take place primarily under the heading of Foreign Direct Investment (FDI), and have downplayed the classic factors of location advantages such as reducing production costs, overcoming barriers to trade, among others (Dunning, 2001).

One of the main strategies of growth and internationalization is currently considered as mergers and acquisitions, given the synergy generated within this process (Cassiman, 2005).

The objective of this work is to review the process of internationalization that the Colombian banks have carried out towards Central America in the light of the eclectic theory of Dunning (1988). In addition to exposing the strategies of internalization that have been carried out by Colombian banks during the last century and during the new stage of internationalization that have been developing since 2000 .

\section{Methods}

There are two crucial reasons to study a process of internationalization of service companies (Cuervo-Cazurra, 2008). The main one is to consider a process that allows the analysis of events in the passage of time, not precisely the relations of variables in a point (Van de Ven and Poole, 1995). The second is to consider a study of those companies to identify good practices that led to success.

In this article it is used the methodology of case study which is not done by representativeness, but with the objective of identifying those tendencies and ideas that were detected directly in the theory (Yin, 1994), therefore it is made case studies of different Colombian banks since Cuervo-Cazurra (2007) points out that a case study allows to establish new ideas that contribute to a better understanding of internationalization processes and facilitates the understanding of the activities that are the result of the decisions taken for the expansion abroad.

The procedures of the chosen method are:

A. Literature review for definition of terms used within the context of the research.

B. Selection of banks to be analyzed, taking into account the following characteristics:

1) To have carried out internationalization processes towards Central America in the period from the year 2000 to the year 2015 .

2) To be the Colombian banks with greater participation in the market.

3) Accessibility to information related to their internationalization processes.

C. Comprehensive review of internationalization strategies of selected Colombian banks.

D. Discussion of theory with empirical evidence.

\section{Referential framework}

Colombian banking is considered one of the most solid in the region, a system with low levels of risk, as well as the balance derived from performance and quality indicators, is positive, remaining around the Latin American average (ASOBANCARIA, 
2015). With regard to solvency and provisions, Colombian banking stands out at the regional level. This situation, added to the instability that the planet lived in the second half of the last decade, helped in the process of internationalization of Colombian banking, in two ways. Firstly, the arrival of foreign banks to the country, and secondly, the internationalization of Colombian banks.

Since the second half of the 1990s, there have been records of the structural reorganization of the Colombian financial system provoked by the economic transformations that took place both at the national and international levels (Sanabria, Hernández, 2004). The process of globalization within the financial sector has repercussions on the Colombian financial system, starting in 1997, when the entry of international banks into the country begins, increasing competition within the sector (Sanabria, Hernández, 2004).

Given the lack of competitiveness of Colombian banks, high intermediation costs, lack of technology and lack of know-how, coupled with their deficiency in customer service, banks are finding it necessary to create survival strategies. Given these shortcomings, with the objective of increasing their competitiveness and survival in the market, national banks chose to merge or acquire banks within the sector, so that the first merger of Banco Industrial Colombiano (BIC) and Banco de Colombia (BC) (Sanabria, Hernández, 2004). With the passage of time in late 1996 and early 1997, strength was recovered in the financial sector given the merger of banks BIC and BC.

Given these results, the BIC begins to look for alternative growths for its strategy of strengthening and growth, from internal to external through merger and acquisition with other companies, to achieve extraordinary profits to compete in a largely dynamic market (Sanabria, Hernández, 2004).

Recently, the crisis of 2008 led different companies from developed countries to sell their operations in different countries of the region, such as HSBC in the banking sector, which decides to sell its operations in different countries of the Central American region, Colombia, Paraguay, Peru, Uruguay (ASOBANCARIA, 2013). In studies carried out by Andonova, Rodíguez and Sánchez (2010), there were 27 mergers and acquisitions of financial intermediation industries in the period 1999-2002 in Colombia, except for insurance and pension and severance funds, in which participated 13 companies, taking third place in the list of industries that carry out mergers and acquisitions.

In 2014, Colombian banks managed to control more than $50 \%$ of the banking business in El Salvador, 13\% in Costa Rica, more than 20\% in Honduras and Nicaragua, 3\% in Guatemala and 20\% in Panama, the largest economy and fastest growing in Central America (ASOBANCARIA, 2013). In South America, Colombian banks are present in Peru and Paraguay mainly, which have maintained good growth rates despite the slowdown in the continent.

Despite the fact that Colombian banks are taking their first steps towards internationalization since the second half of the 20th century. Based mainly on the obtaining of licenses of operation to make new investments, or in the opening of branches mainly in the United States and Panama. It is not until the middle of 2005 when a process begins in a chain of acquisitions, which is presented below (Uribe, 2013). 
Bancolombia, Grupo Aval and Davivienda are the banks selected to carry out the case study review.

\section{Internationalization Process of the Bancolombia Group}

Bancolombia is the leading bank in Colombia. Taking advantage of the environment of optimism in the region as of the crisis of 2008, a series of investments of mergers and acquisitions in the continent has been maintained. Acquisitions have been in the banking sector as well as in the productive sector, such as the acquisition of Nutresa, one of the largest food producers in the region, as well as Conconcreto, an acquisition of approximately USD 137 million. In 1995, she was one of the first Colombian companies to be listed on the Stock Exchange in New York. By 2014, investments abroad represent $35 \%$ of the bank's assets (Latin finance, 2012)

Bancolombia was one of the first banks to open offices abroad in Panama in 1973. Bancolombia Cayman was founded in 1987 in the Cayman Islands and Bancolombia Puerto Rico, whose operating license was initially obtained by Corfinsura, a Colombian financial institution. Then it is acquired by Bancolombia, including its assets in Puerto Rico in 2006 (Revista Dinero, 2015).

Then in 2007 it acquired 100\% of Banco Agrícola in El Salvador, for an amount of USD 900 million, this being its first international acquisition, which allowed it to acquire $30 \%$ of the country's financial market. In 2012, it initially acquires $40 \%$ of BAM, Banco Agromercantil, for USD 216 million, and then acquires 100\% of the bank's control. BAM has 1.1 million customers and 253 branches (Portafolio, 2012).

In 2013 it continued to expand in the region by acquiring Banistmo in Panama, acquiring $90 \%$ of HSBC's shares in the bank for more than USD 2 billion. Bancolombia currently has $14 \%$ of the Panamanian financial market. Additionally, the bank has operations in Peru, through financial institutions (Uribe, 2013).

\section{Internationalization Process of the Aval Group}

The AVAL group is the largest financial conglomerate in Colombia, through its four banks within the country. Banco de Bogotá, Colombia's second largest bank and the longest-running bank with nearly 150 years. It was until 1967 when Banco de Bogotá began its international expansion with an office in Panama, in 1974 the financial institution opened its office in New York, and in the following ten years in the Bahamas and Miami. In order of importance within the AVAL group, Banco de Occidente is the fifth largest bank in Colombia by asset level, which in 1982 opened offices with Banco de Occidente Panamá. The Banco Popular, is leader in the market of libranzas in Colombia and the Bank AV Villas.

As of December 2010, Banco de Bogotá acquires BAC Credomatic Inc., through issuance of Baa3 / BBB- rated debt bonds for an amount of USD 1900 million. BAC Credomatic is a Central American banking conglomerate that operates through its subsidiaries in Costa Rica, El Salvador, Nicaragua, Honduras, Guatemala, Panama, Mexico, Bahamas and Cayman Islands. From 2010 to 2014, the AVAL group managed to double the assets of BAC Credomatic from USD 8 billion to USD 18 billion. Finally, in December 2013, Banco de Bogotá closed the acquisition of BBVA Panama, for which a payment of USD 646 million was agreed, and the financial group Reformador 
in Guatemala for USD 411 million, consolidating its position in Central America (Revista Dinero, 2015).

On the other hand, other smaller financial subsidiaries also began an internationalization process from the year 2000. The Corficolombiana Bank in Panama, subsidiary of Corporación Financiera de Colombia, began operations in 2004, focused on developing investment proposals and business structures. Occidental Bank in Barbados is an offshore bank, started operations in 1991, under the authority of the Barbados financial authority, is $100 \%$ owned by the Bank of the West (Grupo Aval, 2015) (Occident Bank, 2015).

The AVAL group in Central America has a net worth of USD 2.4 billion, employing more than 20,000 people in seven countries, 2400 points of service and more than three million customers (Revista Dinero, 2015).

\section{Process of Internationalization of Davivienda}

Banco Davivienda is Colombia's third largest bank with more than six million clients in Colombia and 743 branches. The bank belongs to the Bolivar Group, which, among others, has one of Colombia's largest insurers in its conglomerate Seguros Bolívar. The bank was founded in 1972 as Coldeahorro, and then changed its name to Davivienda in 1973. Between 2006 and 2007 Davivienda acquires Banco Superior de Colombia, Granbanco and Bancafé, also from Colombia. Davivienda has managed to diversify its portfolio of products, leaving behind the strong dependence on mortgage services (Davivienda, 2015).

The first office abroad is opened in Panama in 1966, and then in 1981 in Miami by Bancafé, in order to support the operations of the Colombian coffee sector abroad. This office would move to Davivienda operations after the acquisition in 2007. In 2012 after negotiations with HSBC, the operations of the Hong Kong Shangai Banking Corporation in Costa Rica, Honduras and El Salvador are acquired for more than USD 800 million. Achieving 810000 clients in Central America, profits of over US \$60 million in 2014 and a portfolio of more than US \$ 4 billion (Latin Finance, 2012).

\section{Discussion}

\section{Internationalization Strategy for Colombian Banks in Latin America}

After reviewing the internationalization processes of Colombian banking in Latin America, mainly in Central America, it is possible to observe that it has been carried out to a greater extent through two strategies:

A. Acquiring operating licenses and authorization from the respective financial authorities of each country.

B. Acquiring the operations of other banks that already had a reputation in the market.

The first strategy of acquiring operating licenses from the country's financial authorities, as mentioned in the description of internationalization processes, was carried out mainly during the second half of the 20th century. Through this strategy, internationalized Colombian banks, rather than gaining market share, seek to posi- 
tion themselves in smaller market niches. This can be seen in the number of branches open in the country of destination, mostly only one branch, with the exception of Davienda Panama with six branches. In addition to the services offered by these branches, mainly focused on investors and entrepreneurs with savings and credit products in dollars and euros (Information obtained from the website of each bank).

A second identifiable strategy is mergers and acquisitions (mostly). As of 2010 the Colombian banks that continued to expand abroad, carried out another strategy to do so. Acquire the operations of existing banks. This allows them to reach the country and take advantage of the resources already had the bank acquired, avoiding to start the operation from scratch.

In this sense, a conjectural aspect marked the acquisitions made by Colombian banks abroad. HSBC, after the legal problems faced by the SwissLeaks case, related to corruption problems in tax evasion, has put its assets in the region for sale. This process of selling its assets, including those of Mexico and Brazil, among others, has been carried out since 2010 approximately (Portafolio, 2015).

\section{Application of eclectic theory to the internationalization of Colom- bian banking in Central America}

\section{Advantages of ownership}

The advantages of ownership are those related to non-tangible assets, mainly, that would provide internationalized banks with a better performance than local banks. Within the property advantages it is possible to find economies of scale, scope, size and bank recognition and product differentiation, its credit rating, among others (Williams, 1997). Yannopoulos (1983) also mentions that product differentiation could take two forms: Taking advantage of the importance of certain currencies or taking advantage of the possibility of not carrying out price competition, but based on services.

Membership in banking networks, knowledge and experience in multinational operations, besides the prestige. These are also recognized as property advantages Cho (1986).

Colombian banks would take advantage of ownership related to size and recognition. In Latin America, Colombian banks by 2013, managed to grow by $42 \%$ and were among the largest banks in the region. Bancolombia, managed to position itself in second place with total assets of USD 55.7 billion for 2012, in addition to having more than 25 thousand employees, double the bank that occupies the first position in size of assets. Third is the Banco de Bogotá with USD 37.4 billion in assets in 2012 and around 10,000 employees. Davivienda in position 8, with total assets of USD26.6 billion in 2012 and more than 10 thousand employees. Finally, in position 10, the Bank of the West with USD 14 billion in assets in 2012 and a little more than six thousand employees (Castrejon, 2014).

With regard to the credit ratings offered by rating agencies, such as Standard \& Poor's, Colombian internationalized entities obtain stable ratings. Davivienda with BBB, Banco de Bogotá and Bancolombia with BBB-. While the Central American banks were also in similar ratings $\mathrm{BB}$ - BBB -, so this may not be a property ad- 
vantage of great impact at the time of internationalization. Credit rating information is available on the institutional website of each bank.

\section{Advantages of internalization}

Within the advantages of internalization, reference is made to the internalization of costs derived from imperfections in product markets and productive factors. Information plays a crucial role in the advantages of internalization. This is based on bank-client relationships, however, there are flaws in the information market (Williams, 1997). Cho (1986) identifies internationalization advantages for internationalized banks, the availability and costs of fund transfers.

The advantages of internalization, given their abstract nature, are probably the most complex to check. Within the different sub-theories that are posed for internationalization from an internalization perspective, one finds the defensive expansion. The defensive expansion, initially discussed by Brimmer and Dahl (1975) implies that banks react to the international expansion of their clients in order to defend the relationship they have maintained with them. Because relationships are informationbased, these flows allow banks to make credit assessments at a lower marginal cost. Switching from one bank to another involves transaction costs for clients and uncertainty, which are internalized when banks are internationalized (Williams, 1997).

The expansion to Central America of companies such as Argos (cement company), which at the beginning of 2015 already had more than 13 plants in the region, EPM (Empresas Públicas de Medellín), EEB (Energy Company of Bogotá) and Celsia in the sector of energy. Grupo Orbis in the production of paintings mainly in the Panamanian market and the group Arturo Calle of textile production, among others. The internationalization and expansion of these companies could lead Colombian banks, under the theory of defensive expansion to expand to defend their trade relations. The expansion of operations would entail the internalization of uncertainty and transaction costs (Dinero, 2015b).

\section{Location Advantages}

The location advantages refer to both the place of arrival and the origin of the bank. These are necessary, but not sufficient to explain whether a bank can compete effectively abroad. Some relevant location advantages are the existence of clients in the host country, entry into growing markets, differences in legislation and regulation that imply benefits upon arrival in the host country (Williams, 1997).

Of the countries of Central America, it is observed that Salvador reported in the third quarter of 2015, economic growth of $2.4 \%$ which exceeds its historical average that had been $2.0 \%$, therefore, it can be said that given this growth credit in this year's business is approximately 1 billion dollars, of which $9.6 \%$ is allocated to the financial sector (Central Reserve Bank of El Salvador, 2015).

The Monthly Index of Economic Activity (IMAE, 2015) focused on the countries of Central America reported a positive behavior to 3\% in August 2015, mainly in Guatemala, growth of $4.1 \%$ and $3.5 \%$ for Honduras and Nicaragua. Growth is mainly represented by economic activities of financial Intermediation, insurance and pension funds, which shows an increase of $8.3 \%$, driven mainly by the growth of financial intermediation (8.7\%) compared to September 2014 when Is reported in $7.9 \%$. 
Panama is the first country with the largest banking sector in Latin America, measured by the volume of deposits divided by its GDP in 2012 according to the Latin American Federation of Banks (FELABAN), Honduras has a $47 \%$ banking, El Salvador $40 \%$, Guatemala 37\%, Costa Rica 36\% and Nicaragua 35\%, therefore given the relatively high percentages of banking, were attractive destinations for Colombian banks since the destinations with medium or low banking income reflect negative factors such as low defense of rights of Property, legal insecurity, and few instruments that drive competition (Pablo, 2013).

\section{Conclusions}

The internationalization of Colombian banking took a new turn as from 2006, when, unlike the processes of internationalization of the last century, they took the strategy of expanding through Foreign Direct Investment, punctually acquiring financial institutions already established in Central America. Banks such as Agrícola, Banistmo, BAM and Credimatic, among others, were acquired over a 10 -year period by entities such as Bancolombia, Banco de Bogotá, Banco de Occidente and Banco Davivienda.

This article analyzes the internalization of the Colombian banks from the year 2000 onwards, based on Dunning's Eclectic Theory, and concludes that the Eclectic theory describes the internationalization of Colombian banks and that they take advantage of the advantages of Property, Localization and Internalization expressed in theory.

Within this paper, information limitations on banking entities are recognized, and strategies and context have been analyzed based on available information. In addition, the analysis of the internalization advantage, which implies greater complexity by the level of abstraction and the information it requires, could be considered as an area of opportunity in future research.

\section{References}

ANDONOVA, V., RODRÍGUEZ-RAMOS, Y., SÁNCHEZ-MANCHOLA, I. (2010). El valor estratégico de la espera en las fusiones y adquisiciones colombianas: 1995-2008. Revista Journal. DOI 10.3232/GCG,2010.V4.N1.03

ASOBANCARIA (2013) La internacionalización de la banca y los retos de la supervisión controlada. Semana Económica. Tercer trimestre.

ASOBANCARIA (2015) La internacionalización de la banca y los retos de la supervisión controlada. Semana Económica. Tercer trimestre.

BANCO CENTRAL DE RESERVAS DE EL SALVADOR (2015). Informe de la situación Econó-

mica Salvadoreña, Septiembre de 2015. Consultado en http://www.bcr.gob.sv/bcrsite/uploaded/content/category/1783688548.pdf

BANK OF THE YEAR, Colombia: Banco de Bogotá. LatinFinance. Nov/Dec2013, Issue 233, p21-21.1p.

URIBE, J. (2013) Internacionalización de la banca colombiana: hechos recientes y retos. Revista Banco de la República. Banco de la República, 1024. 
CALOF, J. L. BEAMISH, P. W. (1995) Adapting to Foreign Markets: Explaining Internationalization. International Business Review 4 (2), p 115-131.

CASSIMAN, B. (2005). El impacto de las fusiones y adquisiciones en la innovación. Universia Business Review, 5, 56-69.

CASTREJON, R. (2014) Los 10 bancos más grandes de Hispanoamérica. Business Review América Latina, publicado el 13 de mayo de 2014. Disponible en: http://www.businessreviewamericalatina.com/finance/564/Los-10-bancos-m\%C3\%A1sgrandes-de-Hispanoam\%C3\%A9rica

CHO, K. (1986) Determinants of international Banks. Management International Review, 26, pp. $10-23$.

CUERVO-CAZURRA, A. (2007). Las distancias en el proceso de internacionalización, el caso del banco Santander. Universia Bussines Review. №. Extra 17, 2008 (Ejemplar dedicado a: 150 aniversario Banco Santander), págs. 96-111

CUERVO-CAZURRA, A., (2008). Sequence of value-added activities in the internationalization of developing country MNEs. Journal of International Management, 13, 258-277.

COASE, R. (1937) The nature of the firm. Economica, 4, pp. 386 - 405.

DAVIVIENDA COLOMBIA BEST BANK: Banco Davivienda. Latin Finance. Nov/Dec2012, Issue 227, p20-20. 1p.

DAVIVIENDA. Sitio web Davivienda. Recuperado el 16 de noviembre de 2015. De https://www.davivienda.com/wps/portal/inversionistasespanol/inversionistas/AcercaBanc o/quienes_somos/davivienda/

DUNNING, J. (1988). The eclectic paradigm of international production: a restatement and some possible extensions. Journal of International Business Studies, 19, 1 - 32.

Dunning, J. (2001). The eclectic (OLI) Paradigm of international production: past, present and future. International Journal of the economic of business, Vol 8, (2), pp. 173-190.

EVERED R. (1983). So what is strategy? Long Range Planning 16(3): 57-72.

GRANT, R. (1991). The Resource-Based Theory of Competitive Advantage: Implications for Strategy Formulation. California Management Review, 33 (3), Spring 1991. 114-135.

GRUPO AVAL. (2015). Pagina corporativa de las compañías pertenecientes al grupo. Recuperado el 15 de noviembre de 2015 de https://www.grupoaval.com/wps/portal/grupoaval/aval/nuestras-companias/bancos

ÍNDICE MENSUAL DE ACTIVIDAD ECONÓMICA (IMAE) Base 2000 (2015) consultado en www.bch.hn

INVESTMENT BANK OF THE YEAR, Colombia: Bancolombia. LatinFinance. Nov/Dec2013, Issue 233, p22-22. 1p.

KORSAKIENE, R. TVARONAVICIENE, M. (2012) The internationalization of SMEs: an integrative approach. Journal of Business Economics \& Management. 13 (2), p 294307.

OCCIDENTAL BANK (2015). Sitio web comporativo. Recuperado el 14 de noviembre de 2015 de https://www.occidentalbankbarbados.com/wps/portal/occidental-barbados/barbados

PABLO, T. (2013). Bancarización en América Latina. 23. 07. 2013 Publicado en http://www.expansion.com/2013/07/23/latinoamerica/economia/1374567449.html 
PORTAFOLIO. (2012) Bancolombia adquiere un 40\% del guatemalteco BAM. Publicada el 18 de diciembre de 2012. Disponible en: http://www.portafolio.co/negocios/bancolombiacompro-acciones-agromercantil

REVISTA DINERO (2015). El país le quedo pequeño a los bancos colombianos. Publicada el 14 de octubre de 2015. Disponible en: http://www.dinero.com/economia/articulo/expansion-bancos-colombianos-centroamerica/214720

SANABRIA, R., HERNÁNDEZ, J. (2004). Fusión del Banco de Colombia y el Banco Industrial Colombiano, Fusión de Carulla S.A. y Almacenes Vivero. Monografías de Administriación, Universidad de los Andes. ISSN 0121-7262.

UNCTAD (2010) World Investment Report 2010: Invertir en unaeconomía de bajo carbono. New York \& Geneva: United Nations Publication. Recuperado de http://unctad.org/es/Docs/wir2010overview_sp.pdf

UNCTAD (2014). Foreign direct investment shows uneven growth in Latin America and the Caribbean, says UNCTAD Report. Informe de prensa. New York \& Geneva: UnitedNationsPublication. Recuperado de http://unctad.org/en/pages/PressRelease.aspx?OriginalVersionID=187

VAN DE VEN, A. H; POOLE, M.S., (1995). Methods for studying innovation development in the Minnesota innovation research program. Organization Science, 1: 313-335.

VILLARREAL, O. (2006). La estrategia de internacionalización de la empresa. Un estudio de casos de multinacionales vascas. Bilbao, España: Universidad del País Vasco.

WILLIAMS, B. (1997). Positive theories of mutinational banking: eclectic theory versus internalization theory. Journal of Economic Surveys, 11 (1), pp. 71 -100.

WILLIAMSON, O. E. (1981). The Economics of Organization: The transaction Cost Approach. American Journal of Sociology, 548-577.

YANNOPOULOS, G.N. (1983) The growth of transnational banking. In M. Casson (ed) The Growth of International Business, (pp. 236-257). Londres, Allen y Unwin.

YIN, R. K., (1994). Case Study Research: Design and Methods. Thousand Oaks, CA: SAGE.

Received: 11/23/2016

Approved: 06/25/2017 